\title{
Intestinal histomorphology in Pseudoplatystoma fasciatum fed bovine colostrum as source of protein and bioactive peptides
}

\author{
Ana Paula Oeda Rodrigues ${ }^{1}$; Patricia Pauletti ${ }^{1}$; Liris Kindlein ${ }^{2}$; Eduardo Francisquine \\ Delgado $^{1}$; José Eurico Possebon Cyrino ${ }^{3}$; Raul Machado-Neto ${ }^{1 *}$ \\ ${ }^{1}$ USP/ESALQ - Depto. de Zootecnia, Laboratório de Anatomia e Fisiologia Animal, C.P. 09 - 13418-900 - \\ Piracicaba, SP - Brasil. \\ ${ }^{2}$ UFRGS/Fac. de Veterinária, Inspeção e Tecnologia de Carnes e Produtos Derivados, Av. Bento Gonçalves, \\ 8834 - $91540-000$ - Porto Alegre, RS - Brasil. \\ ${ }^{3}$ USP/ESALQ - Depto. de Zootecnia, Setor de Piscicultura. \\ *Corresponding author <raul.machado@esalq.usp.br>
}

\begin{abstract}
Histological responses of the intestine are key for evaluating nutritional value of feed ingredients, since the organ is not only the chief site of feed digestion and nutrient absorption but also plays an important immunological function. Histomorphological alterations were evaluated in the intestine of juvenile striped catfish, Pseudoplatystoma fasciatum, fed diets containing 0 (control), 10 or 20\% inclusion of lyophilized bovine colostrum (LBC), as source of protein or bioactive peptides, for either 30 or 60 days. Fish fed 20LBC presented at $60 \mathrm{~d}$ a distinct pattern of macrophages and, some of them, higher number of vacuoles in rectum mucosa. The thickness of the muscle layer (TML) in fish fed diets with LBC was higher in the first portion of medium intestine than fish fed OLBC. All fish presented significant increase of TML in the second portion of medium intestine along feeding period, but fish fed 20LBC had smaller values of TML than those of fish fed 0 and 1OLBC which might be related to the higher intestinal coefficient found for this group. The TML of rectum was higher just for fish fed 10LBC. Dietary LBC altered morphometrical features of juvenile striped catfish intestine and possibly induced inflammatory reaction in the rectal mucosa, as a function of level of inclusion, feeding period and segment of intestine analyzed.
\end{abstract}

Key words: gut absorption, histology, mammal protein, lyophilized bovine colostrum, striped catfish

\section{Histomorfologia intestinal de Psendoplatystoma fasciatum alimentado com colostro bovino como fonte de proteína e peptídeos bioativos}

\begin{abstract}
RESUMO: Respostas histológicas do intestino são fundamentais para avaliar o valor nutritivo de ingredientes alimentares, uma vez que o órgão não é só o principal local de digestão e absorção dos nutrientes, mas também exerce uma importante função imunológica. Alterações histomorfológicas foram avaliadas no intestino de juvenis de cachara, Pseudoplatystoma fasciatum, alimentado com dietas contendo 0 (controle), 10 e $20 \%$ de inclusão de colostro bovino liofilizado (CBL) como fonte de proteína e peptídeos bioativos, aos 30 e 60 dias. Aos 60 dias, peixes alimentados com 20CBL apresentaram macrófagos de aspecto distinto e alguns, uma grande concentração de vacúolos na mucosa retal. A espessura da camada muscular (ECM) em peixes alimentados com CBL foi maior na primeira porção do intestino médio em relação àqueles alimentados com OCBL. Ao longo do período experimental, todos os peixes mostraram aumento significativo na ECM na segunda porção do intestino médio, entretanto peixes do grupo 20CBL tiveram menores valores para a ECM do que os demais, o que pode estar relacionado com o maior coeficiente intestinal encontrado para este grupo. A ECM no reto foi maior apenas para os peixes alimentados com 10CBL. A inclusão de CBL na dieta do cachara alterou características morfométricas do intestino e, possivelmente, induziu uma reação inflamatória na mucosa retal em função do nível de inclusão, período de alimentação e porção do intestino analisada.

Palavras-chave: absorção intestinal, histologia, proteína láctea, colostro bovino liofilizado, cachara
\end{abstract}

\section{Introduction}

Knowledge on anatomical and morphophysiological features of fish digestive tract set bases for the study of fish nutrition (Datta Munshi and Dutta, 1996; Evans et al., 2005; Pezzato et al., 2004). Aslaksen et al. (2007), Romarheim et al. (2008), Urán et al. (2008) and Øverland et al. (2009), have regarded histological responses of the intestine as a supplementary tool to evaluate the nutritional value of an ingredient, since the organ is not only the chief site of feed digestion and absorption of nutrients but also plays an important immunological function (Buddington et al., 1997).

The bovine colostrum is a complex food source, with high contents of proteins and a diversity of biologically active molecules, such as growth factors, especially insulin-like growth factors (IGFs) (Blum and Hammon, 2000; Foley and Otterby, 1978; Pakkanen and Aalto, 1997). The IGFs are peptides bearing mytogenic and antiapoptotic properties that can modulate the cellular ki- 
netics through both autocrine and paracrine routes, thus modulating growth, development and differentiation of several body tissues (Baumrucker and Blum, 1993; Butler et al., 1998; Howarth, 2003; Pakkanen and Aalto, 1997). High cost and low availability of bovine colostrum may hamper its broad use in animal feeds. However, studying its inclusion in fish diets would provide information about the intestinal mechanisms of absorption by the concomitant evaluation of the effects of mammal protein and growth factors orally administered to fish.

The South American striped catfish Pseudoplatystoma fasciatum Linnaeus 1776 (Siluriforms: Pimelodidae) is a prized carnivorous fish with farming potential for sport fisheries, food-fish or ornamental fish trade, which has been explored for fish culture in Brazil since late 1980s (Campos, 2005). Therefore, research on farmed striped catfish performance, behavior and physiology is yet understandably recent and relatively scarce (Leonardo et al., 2004, 2006; Romagosa et al., 2003 a, b). Although intestinal anatomy and histology of striped catfish had already been described by Rodrigues et al. (2009), there is a lack on studies on the species' intestinal absorptive mechanisms. This study evaluates the occurrence of histomorphological alterations in the intestine of striped catfish, fed diets containing varying levels of bovine colostrum as protein and bioactive peptides source.

\section{Material and Methods}

Farm-raised, feed-conditioned juvenile striped catfish were stocked in 60-L, covered plastic cages housed in concrete tanks within a greenhouse, in a closed, continuous water circulation and aeration system $\left(28 \pm 2{ }^{\circ} \mathrm{C}\right)$. Fish were acclimated to experimental routine feeding to apparent satiety twice a day (7h00 and 16h00) for four weeks on a commercial carnivorous fish feed (45\% crude protein - CP; 3,000 kcal kg ${ }^{-1}$ gross energy - GE). Upon the end of the acclimatization period, fish [35.35 \pm 2.11 $\left.\mathrm{g} ; \mathrm{L}_{\mathrm{S}}=14.39 \pm 0.53 \mathrm{~cm}\right]$ were assigned to experimental groups in a totally randomized design, $3 \times 2$ factorial scheme with three diets - $O$ (control), 10 and 20\% inclusion lyophilized bovine colostrum (LBC) - and two feeding periods -30 and 60 days $(n=3 ; 12$ fish per cage). The bovine colostrum pool was obtained from multiparous dairy cows in Piracicaba, state of São Paulo, Brazil. The material was centrifuged twice for partial extraction of fat fraction (10 min.; $12,000 \mathrm{~g}, 4^{\circ} \mathrm{C}$ ), and subsequently homogenized and frozen for the lyophilization procedure. Formulation of experimental, approximately isonitrogenous, pelleted diets and their centesimal composition are presented on Table 1. Experimental diets and LBC were submitted to chemical analysis according to AOAC (2000) methods (Tables 1 and 2). Concentration of insulin-like growth factor - I (IGF-I) in the LBC was quantified through post-extraction immunoradiometric assay kit (Diagnostic Systems Laboratories Inc., Webster, TX, USA). Lyophilized colostrum was reconstituted with milk and centrifuged for $30 \mathrm{~min}$. at 13,000 x $g$ (Vega et al., 1991). Peptides were extracted from sampled colostrum aliquots under acid ethanol treatment and quantified in a gamma counter. The estimated concentrations of IGF-I in the experimental diets are presented in Table 2.

Table 1 - Chemical composition of the experimental diets.

\begin{tabular}{|c|c|c|c|}
\hline \multirow{2}{*}{ Ingredients } & \multicolumn{3}{|c|}{ Percent in dieta } \\
\hline & Control & 10LBC & $20 \mathrm{LBC}$ \\
\hline Colostrum (68.52\%) & - & 10 & 20 \\
\hline Fish meal $(60 \% \mathrm{CP})$ & 25 & 25 & 20 \\
\hline Corn gluten meal $(60 \% \mathrm{CP})$ & 22 & 22 & 17.7 \\
\hline Soybean meal (45\% CP) & 15 & 5 & 2.3 \\
\hline Wheat meal & 14 & 14 & 14 \\
\hline Poultry by-product meal (57.8\% CP) & 10 & 10 & 10 \\
\hline Soybean oil & 7.6 & 12 & 14 \\
\hline Corn (whole grain) & 4.4 & - & - \\
\hline Mineral and vitamin mixb & 2 & 2 & 2 \\
\hline Nutrient contentsc & Control & 10LBC & 20LBC \\
\hline Moisture & 4.15 & 4.18 & 11.51 \\
\hline Crude protein $(\mathrm{CP})$ & 48.77 & 51.44 & 49.72 \\
\hline Lipids & 16.31 & 18.91 & 20.57 \\
\hline Ash & 8.37 & 8.16 & 7.49 \\
\hline \multicolumn{4}{|c|}{ 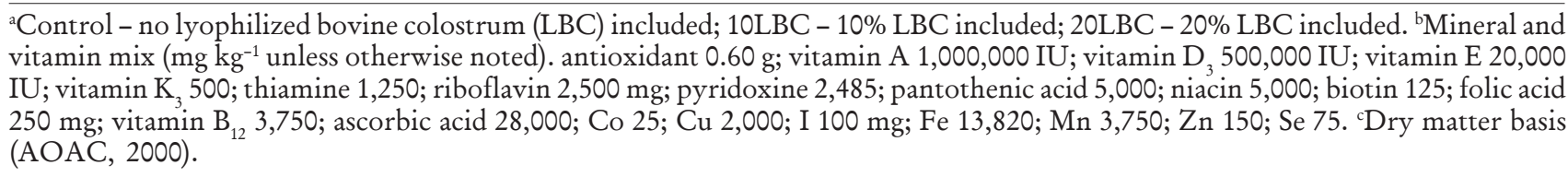 } \\
\hline
\end{tabular}


Fish fasted for $24 \mathrm{~h}$ were randomly sampled (seven fish per treatment), euthanized by anesthetic overdoses (benzocaine; $5.0 \mathrm{~g} \mathrm{~L}^{-1}$ ), measured, weighted, and laparotomized. Intestinal tracts (IT, pyloric sphincter to anus) were then isolated, measured (intestinal length, $\mathrm{L}_{\mathrm{TT}}$ ), separated into medium intestine and rectum by identification of the ileum-rectal valve (Bértin, 1958), and the former divided into two segments: S1 (anterior section; rectilinear) and S2 (posterior section; convolute).

Intestines regions were fixed in buffered $(0.1 \mathrm{M}, \mathrm{pH}$ 7.2 ), $4 \%$ p-formaldehyde solution, and sub-divided into 5 - $\mathrm{mm}$ sections, which were washed in phosphate buffer solution (0.1.M, $\mathrm{pH} 7.2$ ) four consecutive times. Washed material was dehydrated by immersion in increasing ethanol concentrations: $30,50,70,90$, and $100 \%$ (3x in the last one), and submitted to pre-infiltration with glycol-methacrylate resin diluted in ethanol 100\% (1:1). The material was then embedded in pure glycol-methacrylate resin, and transversal, non-sequential, $5-\mu \mathrm{m}$ sections were processed for staining with $0.05 \%$ toluidine-blue O (Sigma Chemical Company, St. Louis, MO, USA) solution, buffered with citric acid and anhydrate bi-phosphate solution ( $\mathrm{pH} 4.5)$.

Histological analysis - thickness of the muscle layer (TML; 10 fields per segment at 100x magnification); number of goblet cells in the rectum (NGC; 20 fields at 200x magnification); observation of abnormal features in the rectal mucosa - was performed and images taken in light microscope coupled to Axio-Vision 2.05 image analysis system. Intestinal coefficients $\left(\mathrm{IC}=\mathrm{L}_{\mathrm{TT}} / \mathrm{L}_{\mathrm{s}}\right.$ ) were also estimated for each sampled fish (Bértin, 1958). Histomorphometrical data and IC were submitted to two-way ANOVA by PROC MIXED procedures (SAS, 1991); Tukey test $(\alpha=0.05)$ was used for detection of statistical differences of means (Steel and Torrie, 1980). All numerical results are given by media \pm standard deviation.

Table 2 - Chemical composition of lyophilized bovine colostrum.

\begin{tabular}{lc}
\hline Nutrient & Percent contents $^{\mathrm{a}}$ \\
\hline Dry matter & 95.49 \\
Crude protein & 68.52 \\
Lipids & 15.00 \\
Ash & 3.69 \\
\hline IGF-I & $\mu^{-1}$ kg $^{-1}$ diet $^{\mathrm{c}}$ \\
\hline Control $^{\mathrm{b}}$ & 0 \\
10LBC $^{\mathrm{b}}$ & 97.2 \\
\hline 20LBC & 194.4 \\
\hline
\end{tabular}

${ }^{a}$ Dry matter basis (AOAC, 2000). ${ }^{\mathrm{b}}$ Control - no lyophilized bovine colostrum (LBC) included; 10LBC - 10\% LBC included; 20LBC - 20\% LBC included. 'Estimated values after IGF-I quantification in lyophilized bovine colostrum by immunoradiometric assay. IGF-I - insulin-like growth factor I.

\section{Results and Discussion}

At day 30 and 60, final weight and standard length were similar between fish fed the diets $(p>0.05)$ : 61.16 $\pm 4.81 \mathrm{~g} ; 17.78 \pm 0.76 \mathrm{~cm}$, and $102.44 \pm 13.35 \mathrm{~g} ; 19.81 \pm$ $1.54 \mathrm{~cm}$, respectively. Diets or extension of feeding period did not influence NGC in the rectum (Table 3). However, fish fed diet 20LBC presented at day 60 a distinct pattern of macrophages, which predominate in the apical portion of intestinal folds, exhibited a distinct staining pattern, and were apparently bigger than those found in fish fed the control or 10LBC diets (Figure 1). Some fish fed the 20LBC diet also presented at day 60 higher incidence of vacuoles in the intestinal mucosa (Figure 2).

Fish fed diet 20LBC presented higher IC $(p \leq 0.05)$ than fish fed diets control or 10LBC (Table 4). At day 60 , fish had smaller IC than at day $30(p \leq 0.05)$. Fish fed diets containing LBC presented higher values of TML in the S1 portion of medium intestine $(p \leq 0.05)$ in comparison to fish fed the control diet (Table 5). All fish presented significant increase of TML in S2 along the experimental period, but fish fed diet 20LBC presented values of TML smaller than those of fish fed diets control and 10LBC $(p \leq 0.05)$. The TML of rectum was affected only by diets; and was higher for fish fed diet 10LBC $(p \leq 0.05)$ (Table 5).

Proximal portions of fishes' intestines are credited with higher nutrient digestibility and absorption, and overall digestive capacity; the distal portions of fishes' intestines are important for absorption of intact proteins and peptides molecules (Bakke-McKellep et al., 2000; Ezeasor and Stokoe, 1981; Krogdahl et al., 2003; Ledger et al., 2002; Ostaszewska et al., 2005; van den Ingh et al., 1991). This ability of distal intestine may be related to its attributed immunological function (Georgopoulou and Vernier, 1986; Jenkins et al., 1994; Rombout et al., 1985; Rombout and van den Berg, 1989).

Fish fed diets 10LBC and 20LBC presented increase of TML in S1, possibly as a result of increased activity of absorption processes in this part of the intestine. On the other hand, the reduced TML observed for fish fed diet 20LBC in S2 might be related to the higher IC induced by ingestion of LBC, since the increasing of the intestinal length could have narrowed the TML in S2. In the rectum, probably because of its naturally increased permeability and immunological sensitivity, increased TML was registered only for fish fed diet 10LBC, deemed adequate for growth promotion, seeing

Table 3 - Average number of goblet cells in the rectum.

\begin{tabular}{lccc}
\hline \multirow{2}{*}{ Feeding period } & \multicolumn{3}{c}{ Experimental group $^{\mathrm{a}}$} \\
\cline { 2 - 4 } & Control & 10LBC & 20LBC \\
\hline 30 days & $28.53 \pm 6.98$ & $31.85 \pm 7.88$ & $33.46 \pm 7.60$ \\
60 days & $31.53 \pm 7.16$ & $30.59 \pm 7.58$ & $32.24 \pm 7.47$
\end{tabular}

${ }^{a}$ Control - no lyophilized bovine colostrum (LBC) included; 10LBC - 10\% LBC included; 20LBC - 20\% LBC included. 
Table 4 - Intestinal coefficient (IC) of juvenile striped catfish Pseudoplatystoma fasciatum fed diets containing lyophilized bovine colostrum for 30 or 60 days.

\begin{tabular}{|c|c|c|c|c|c|c|c|}
\hline \multirow{3}{*}{ Feeding period } & \multicolumn{3}{|c|}{ Experimental group ${ }^{a}$} & & \multicolumn{3}{|c|}{ Probability $^{\mathrm{b}}$} \\
\hline & Control & 10LBC & 20LBC & & Diet & Period & Diet $X$ period \\
\hline & & $\mathrm{IC}$ & & Mean & & & \\
\hline 30 days & $0.84 \pm 0.05$ & $0.82 \pm 0.08$ & $0.92 \pm 0.03$ & $0.86 \pm 0.07^{x}$ & \multirow{2}{*}{$\leq 0.05$} & \multirow{2}{*}{$\leq 0.05$} & \multirow{2}{*}{$\mathrm{ns}^{*}$} \\
\hline 60 days & $0.68 \pm 0.08$ & $0.75 \pm 0.07$ & $0.76 \pm 0.06$ & $0.73 \pm 0.07^{Y}$ & & & \\
\hline Mean & $0.76 \pm 0.10^{x}$ & $0.78 \pm 0.08^{x}$ & $0.84 \pm 0.10^{y}$ & & & & \\
\hline
\end{tabular}

${ }^{\mathrm{a} C}$ Control - no lyophilized bovine colostrum (LBC) included; 10LBC - 10\% LBC included; 20LBC - 20\% LBC included. ${ }^{\mathrm{b}}$ Probability: diet $\mathrm{X}$ feeding period - interaction diet x period. *ns: not significant. ${ }^{\mathrm{X}}$ Y Values followed by the same capital superscript in the same column do not differ (Tukey test; $p \leq 0.05$ ). ${ }^{\mathrm{x}, \mathrm{y}}$ Values followed by the same lower case superscript in the same line do not differ (Tukey test; $p \leq 0.05)$.

Table 5 - Thickness of the muscle layer (TML) of the intestine of juvenile striped catfish Pseudoplatystoma fasciatum fed diets containing lyophilized bovine colostrum for 30 or 60 days.

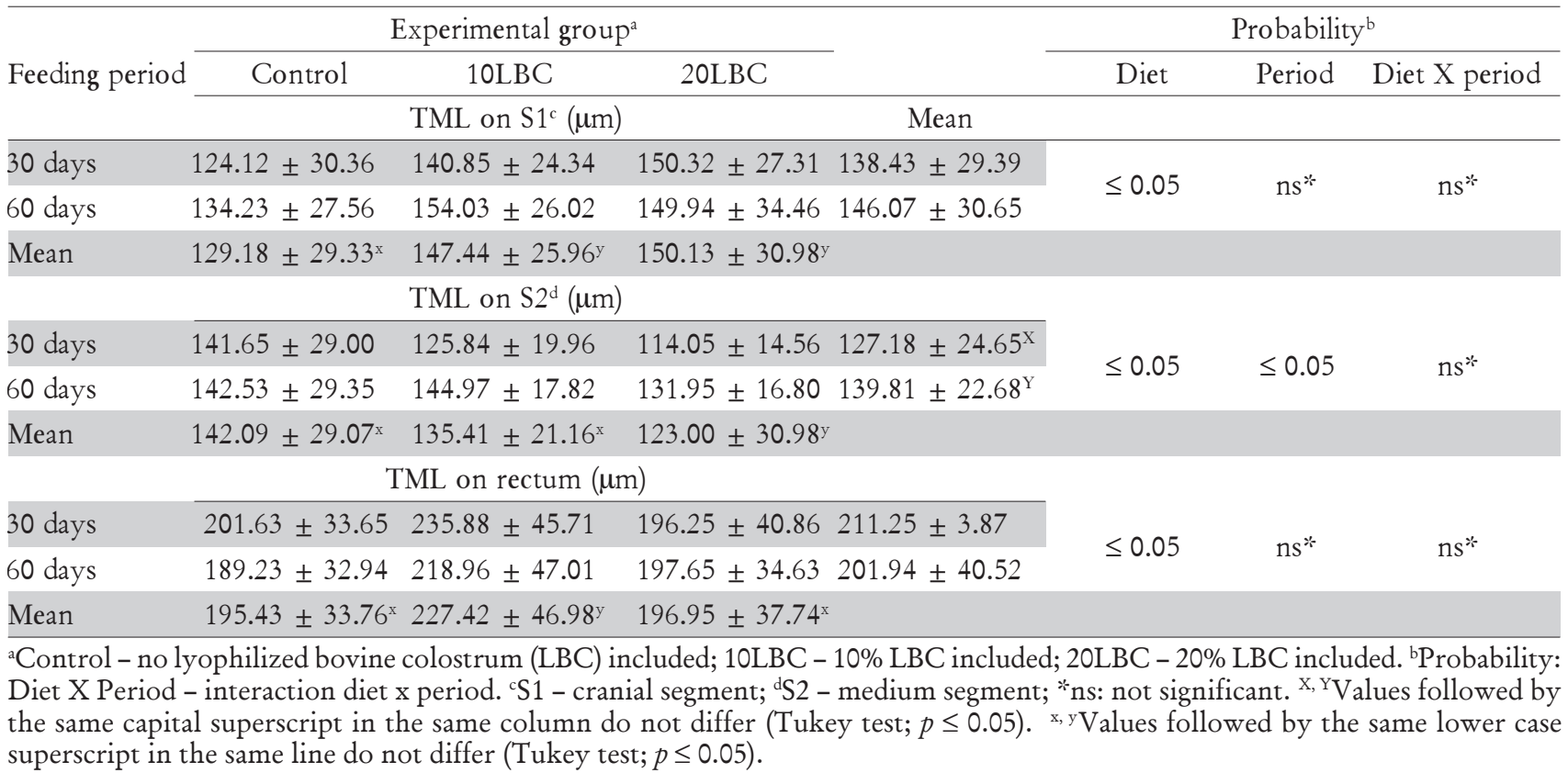

that the rectal mucosa of fish fed diet 20LBC presented a pathohistological reaction at day 60, which may have reduced the capacity of absorption of nutrients. Peterson et al. (1996) studied the effect of IGF-I supply in rats under total parenteral nutrition found augment jejunal mucosal weight, and increased villus height and crypt depth. Bühler et al. (1998) and Roffler et al. (2003) found an increase in intestinal villus size from neonatal calves fed bovine colostrum.

At day 60, fish fed diet 20LBC presented a pattern of macrophages (Figure 1) distinct from that observed at day 30 for fish fed any of the experimental diets, which can be have resulted from the complex composition of LBC and, therefore, its potential antigenic function for fishes. Rombout and van den Berg (1989) administered antigens via anal to carp, and registered increased number of macrophages in the distal intestine; the authors also considered the observed, enlarged intraepithelial macrophages morphologically similar to melanomacrophages, thus able to drive local immune response. Melanomacrophages are pigmented macrophages aggregates, ordinarily found in the kidney, liver and spleen of bony fish (Agius and Roberts, 2003; Haugarvoll et al., 2006; Wolke, 1992), or adventitiously to inflamed regions (Koppang et al., 2005; Rodríguez et al., 2005); functions of melanomacrophages are multiple, complex and not yet totally understood. Although the distinct staining pattern, form and size of macrophages observed at day 60 in the intestines of fish fed diet 20LBC are similar to that of melanomacrophages, it is not possible to confirm this hypothesis by the histological techniques utilized.

Large and numerous vacuoles detected in the distal intestine of some fish fed diet 20LBC at day 60 (Figure 2) can be correlated with the higher inclusion of dietary lipids sources in diets 10 and 20LBC (Table 1), as well as with a pathohistological condition. According to Burrells et al. (1999), same as for livers, lipid vacuoles 


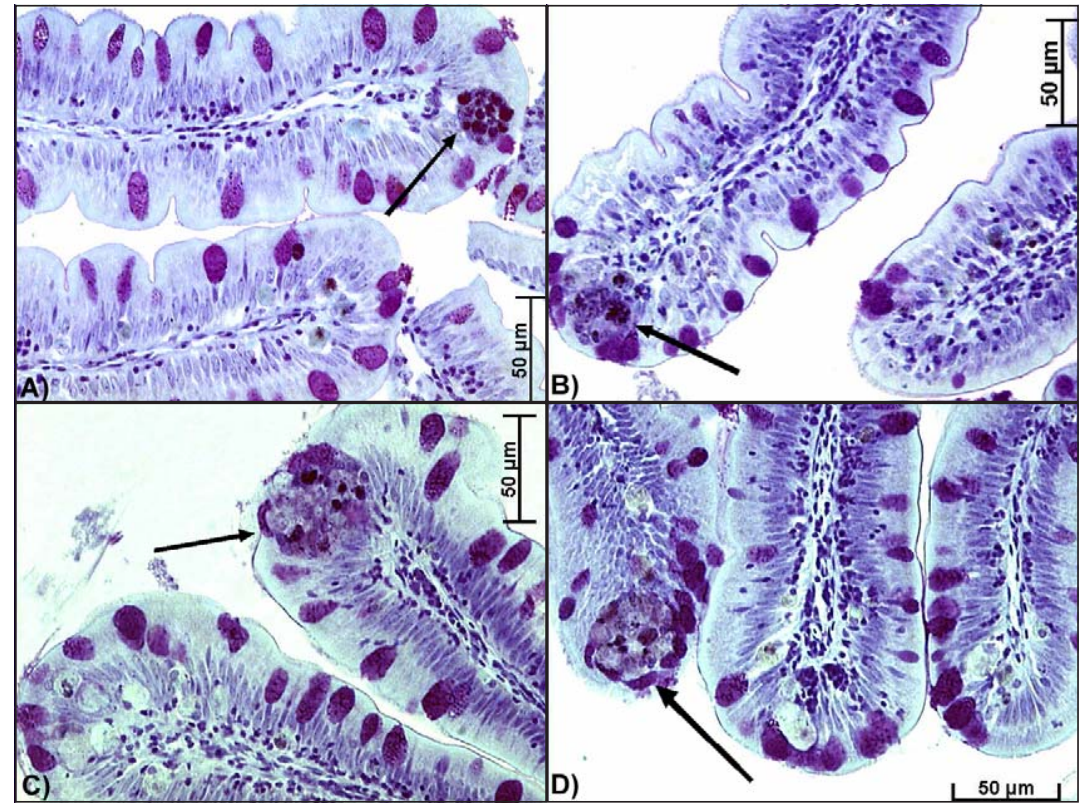

Figure 1 - Macrophages (arrows) in the rectal mucosa at 60 days: (A) fish fed control diet; (B) fish fed diet containing 10\% lyophilized bovine colostrum; (C) and (D) fish fed diet containing 20\% lyophilized bovine colostrum (400x).

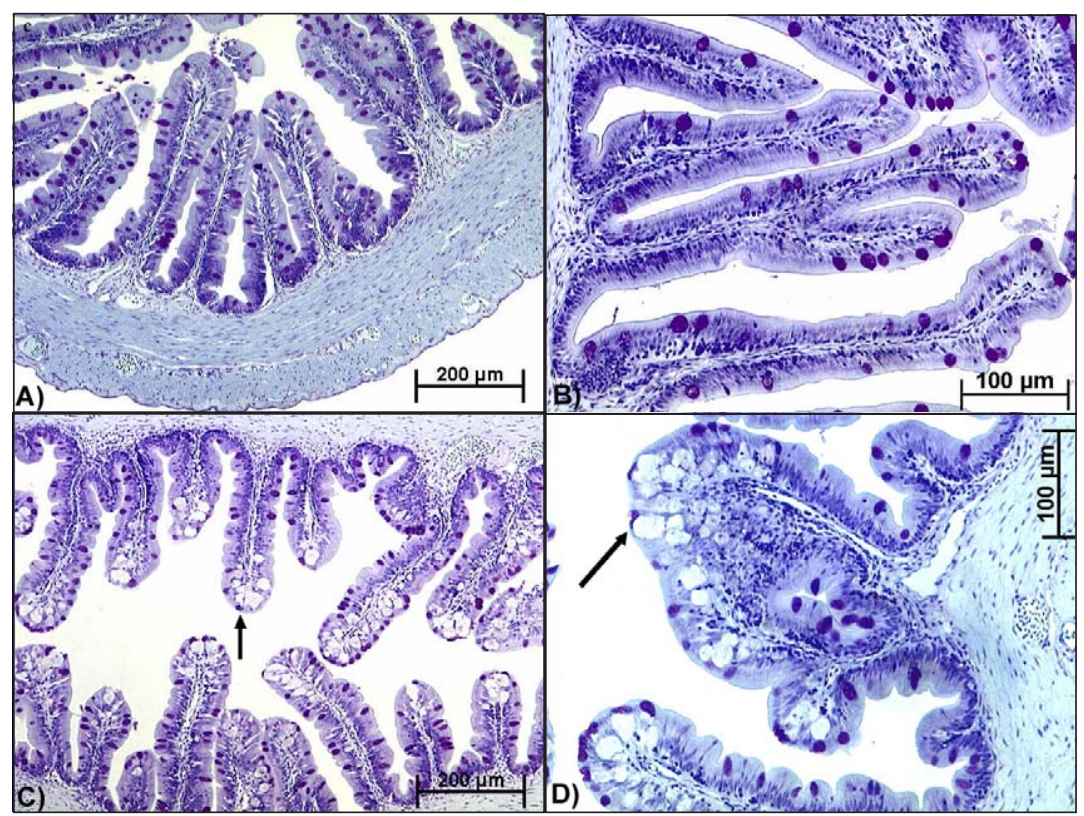

Figure 2 - Vacuoles (arrows) in the rectal mucosa at 60 days: (A) fish fed control diet (100x); (B) fish fed diet containing $10 \%$ lyophilized bovine colostrum (200x); (C) and (D) fish fed diet containing 20\% lyophilized bovine colostrum (100x and 200x, respectively).

in the intestine are studied because they are generally considered temporary storage site of lipids, particularly when the absorption level exceeds the lipoprotein synthesis capacity. On the other hand, Ostaszewaska et al. (2005) reported the presence of large vacuoles in the digestive tract of rainbow trout Oncorbyncus mykiss and pacu Piaractus mesopotamicus, considered those findings a pathological reaction to the replacement of casein with soybean protein concentrate in the diet of these species, and suggested that these vacuoles can lessen intestinal nutrient absorption. Burrells et al. (1999) and SitjáBobadilla et al. (2003) also consider that the presence of vacuoles in fishes' intestinal epithelium results in a loss of the mucosa integrity, which reduces fish specific growth rate and increase susceptibility to bacterial infection.

In conclusion, the inclusion of LBC in diets of striped catfish altered morphometrical features of juvenile striped catfish intestine and induced inflammatory reaction in the distal intestinal mucosa, depending on level 
of inclusion, feeding period and segment of intestine analyzed. This information may elicit better understanding of fishes' intestinal mechanisms of absorption and foster future researches in this area.

\section{Acknowledgements}

To technical staff and students of Setor de Piscicultura (Fish Culture Section) and Laboratório de Anatomia e Fisiologia Animal (Animal Anatomy and Physiology Laboratory - LAFA), Departamento de Zootecnia, and Núcleo de Apoio à Pesquisa em Microscopia Eletrônica Aplicada a Agricultura (Applied Electronic Microscopy Support Nucleous - NAP/ MEPA) for all the help with the sampling, processing and histological analysis activities. This study was supported by "Fundação de Amparo à Pesquisa do Estado de São Paulo - FAPESP" (Grant \# 04/09721-3). "Conselho Nacional de Desenvolvimento Científico e Tecnológico - CNPq" provided undergraduate research scholarship for the first autor.

\section{References}

Agius, C.; Roberts, R.J. 2003. Melano-macrophage centres and their role in fish pathology. Journal of Fish Diseases 26: 499509.

Aslaksen, M.A.; Kraugerud, O.F.; Penn, M.; Svihus, B.; Denstadli, V.; Jørgensen, H.Y.; Hillestad, M.; Krogdahl, Å.; Storebakken, T. 2007. Screening of nutrient digestibilities and intestinal pathologies in Atlantic salmon, Salmo salar, fed diets with legumes, oilseeds, or cereals. Aquaculture 272: 541-555.

Association of Official Analytical Chemists [AOAC]. 2000. Official Methods of Analysis. 17ed. AOAC, Washington, DC, USA.

Bakke-McKellep, A.M.; Nordrum, S.; Krogdahl, Å.; Buddington, R.K. 2000. Absorption of glucose, amino acids, and dipeptides by the intestines of Atlantic salmon (Salmo salar L.). Fish Physiology and Biochemistry 22: 33-44.

Baumrucker, C.R.; Blum, J.W. 1993. Secretion of insulin-like growth factors in milk and their effect in the neonate. Livestock Production Science 35: 49-74.

Bértin, L. 1958. Digestive tract. v.13, p. 1249-1301. In: Grassé, P.P., ed. Traité de zoologie, Masson, Paris, France. (in French).

Blum, J.W.; Hammon, H. 2000. Colostrum effects on the gastrointestinal tract, and on nutritional, endocrine and metabolic parameters in neonatal calves. Livestock Production Science 66: 151-159.

Buddington, R.K.; Krogdahl, Å.; Bakke-McKellep, A.M. 1997. The intestines of carnivorous fish: structure and functions and the relations with diet. Acta Physiologica Scandinavica 161: 67-80.

Bühler, C.; Hammon, H.; Rossi, G.L.; Blum, J.W. 1998. Small intestinal morphology in eight-day-old calves fed colostrum for different durations or only milk replacer and treated with longR3-insulin-like growth factor I and growth hormone. Journal of Animal Science 76: 758-765.

Burrells, C.; Williams, P.D.; Southgate, P.J.; Crampton, V.O. 1999. Immunological, physiological and pathological responses of rainbow trout (Oncorhynchus mykiss) to increasing dietary concentrations of soybean proteins. Veterinary Immunology Immunopathology 72: 277-288.

Butler, A.A.; Yakar, S.; Gewolb, I.H.; Karas, M.; Okubo, Y.; LeRoith, D. 1998. Insulin-like growth factor-I receptor signal transduction: at the interface between physiology and cell biology. Comparative Biochemistry and Physiology 121B: 1926.
Campos, J.L. 2005. The farming of the speckled catfish, Pseudoplatystoma coruscans (Spix e Agassiz, 1829). p. 327-343. In: Baldisserotto, B.; Gomes, L.C., eds. Espécies nativas para piscicultura no Brasil. Editora da UFSM, Santa Maria, RS, Brazil. (in Portuguese).

Datta Munshi, J.S.; Dutta, H.M., 1996. Fish Morphology: Horizon of New Research. Science, Enfield, NH, USA.

Evans, J.J.; Pasnik, D.J.; Peres, H.; Lim, C.; Klesius, P.H. 2005. No apparent differences in intestinal histology of channel catfish (Ictalurus punctatus) fed heat-treated and non-heat-treated raw soybean meal. Aquaculture Nutrition 11: 123-129.

Ezeasor, D.N.; Stokoe, W.M. 1981. Light and electron microscopic studies on the absorptive cells of the intestine, caeca and rectum of the adult rainbow trout, Salmo gairdneri, Rich. Journal of Fish Biology 18: 527-544.

Foley, J.A.; Otterby, D.E. 1978. Availability, storage, treatment, composition, and feeding value of surplus colostrum: a review. Journal of Dairy Science 61: 1033-1060.

Georgopoulou, U.; Vernier, J.M. 1986. Local immunological response in the posterior intestinal segment of the rainbow trout after oral administration of macromolecules. Developmental and Comparative Immunology 10: 529-537.

Haugarvoll, E.; Thorsen, J.; Laane, M.; Huang, Q.; Koppang, E.O. 2006. Melanogenesis and evidence for melanosome transport to the plasma membrane in a $\mathrm{CD} 83^{+}$teleost leukocite cell line. Pigment Cell Research 19: 214-225.

Howarth, G.S. 2003. Insulin-like growth factor-I and the gastrointestinal system: therapeutic indications and safety implications. The Journal of Nutrition 133: 2109-2112.

Jenkins, P.G.; Wrathmell, A.B.; Harris, J.E.; Pulsford, A.L. 1994. Systemic and mucosal immune responses to enterically delivered antigen in Oreochromis mossambicus. Fish \& Shellfish Immunology 4: 255-271.

Koppang, E.O.; Haugarvoll, E.; Hordvik, I.; Aune, L.; Poppe, T.T. 2005. Vaccine-associated granulomatous inflammation and melanin accumulation in Atlantic salmon, Salmo salar L., white muscle. Journal of Fish Diseases 28: 13-22.

Krogdahl, Å.; Bakke-McKellep, A.M.; Baeverfjord, G. 2003. Effects of graded levels of standard soybean meal on intestinal structure, mucosal enzyme activities, and pancreatic response in Atlantic salmon (Salmo salar L.). Aquaculture Nutrition 9: 361-371.

Ledger, R.; Tucker, I.G.; Walker, G.F. 2002. The metabolic barrier of the lower intestinal tract of salmon to the oral delivery of protein and peptide drugs. Journal of Controlled Release 85: 91-103.

Leonardo, A.F.G.; Romagosa, E.; Batlouni, S.R.; Borella, M.I. 2006. Occurrence and significance of ovarian and follicular regression in cachara Pseudoplatystoma fasciatum (Linnaeus, 1766): a histology approach. Arquivo Brasileiro de Medicina Veterinária e Zootecnia 58: 831-840.

Leonardo, A.F.G.; Romagosa, E.; Borella, M.I.; Batlouni, S.R. 2004. Induced spawning of hatchery-raised Brazilian catfish, cachara Pseudoplatystoma fasciatum (Linnaeus, 1766). Aquaculture 240: 451-461.

Ostaszewska, T.; Dabrowski, K.; Palacios, M.E.; Olejniczak, M.; Wieczorek, M. 2005. Growth and morphological changes in the digestive tract of rainbow trout (Oncorbyncus mykiss) and pacu (Piaractus mesopotamicus) due to casein replacement with soybean proteins. Aquaculture 245: 273-286.

Øverland, M.; Sørensen, M.; Storebakken, T.; Penn, M.; Krogdahl, Å.; Skrede, A. 2009. Pea protein concentrate substituting fish meal or soybean in diets for Atlantic salmon (Salmo salar): effect on growth performance, nutrient digestibility, carcass composition, gut health, and physical feed quality. Aquaculture 288: 305-311.

Pakkanen, R.; Aalto, J. 1997. Growth factors and antimicrobial factors of bovine colostrum. International Dairy Journal 7: 285-297.

Peterson, C.A.; Ney, D.M.; Hinton, P.S.; Carey, H.V. 1996. Beneficial effects of insulin-like growth factor I on epithelial structure and function in parenterally fed rat jejunum. Gastroenterology 111: 1501-1508. 
Pezzato, L.E.; Barros, M.M.; Fracalossi, D.M.; Cyrino, J.E.P. 2004. Fish nutrition. p. 75-169. In: Cyrino, J.E.P.; Urbinati, E.C.; Fracalossi, D.M.; Castagnolli, N., eds. Tópicos especiais em piscicultura de água doce tropical intensiva. TecArt, São Paulo, SP, Brazil. (in Portuguese).

Rodrigues, A.P.O.; Pauletti, P.; Kindlein, L.; Cyrino, J.E.P.; Delgado, E.F.; Machado-Neto, R. 2009. Intestinal morphology and histology of the striped catfish Pseudoplatystoma fasciatum (Linnaeus, 1766) fed dry diets. Aquaculture Nutrition 15: 559563.

Rodríguez, A.; Gisbert, E.; Rodríguez, G.; Castelló-Orvay, F. 2005. Histopathological observations in European glasss eels (Anguilla anguilla) reared different diets and salinities. Aquaculture 244: 203-214.

Roffler, B.; Fäh, A.; Sauter, S.N.; Hammon, H.M.; Gallmann, P.; Brem, G.; Blum, J.W. 2003. Intestinal morphology, epithelial cell proliferation, and absorptive capacity in neonatal calves fed milk-born insulin-like growth factor-I or a colostrum extract. Journal of Dairy Science 86: 1797-1806.

Romagosa, E.; Paiva, P.; Andrade-Talmelli, E.F.; Godinho, H.M. 2003a. Reproductive biology of female stripped catfish, Pseudoplatystoma fasciatum (Teleostei, Siluriformes, Pimelodidae), kept in captivity. Boletim do Instituto de Pesca: 29: 151-159. (in Portuguese, with abstract in English).

Romagosa, E.; Paiva, P.; Godinho, H.M.; Andrade-Talmelli, E.F. 2003b. Morphometrics and growth of stripped catfish, Pseudoplatystoma fasciatum (Linnaeus, 1766), in captivity. Acta Scientiarum. Animal Sciences 25: 277-283. (in Portuguese, with abstract in English).

Romarheim, O.H.; Zhang, C.; Penn, M.; Liu, Y-J.; Tian, L-X.; Skrede, A.; Krogdahl, A.; Storebakken, T. 2008. Growth and intestinal morphology in cobia (Rachycentron canadum) fed extruded diets with two types of soybean meal partly replacing fish meal. Aquaculture Nutrition 14: 174-180.

Rombout, J.H.W.M.; Lamers, C.H.J.; Helfrich, M.H.; Dekker, A.; Taverne-Thiele, J.J. 1985. Uptake and transport of intact macromolecules in the intestinal epithelium of carp (Cyprinus carpio L.) and the possible immunological implications. Cell and Tissue Research 239: 519-530.
Rombout, J.H.W.M.; van den Berg, A.A. 1989. Immunological importance of the second gut segment of carp. I. Uptake and processing of antigens by epithelium cells and macrophages. Journal of Fish Biology 35: 13-22.

Sitjá-Bobadilla, A.; Mingarro, M.; Pujalte, M.J.; Garay, E.; AlvarezPellitero, P.; Pérez-Sánchez, J. 2003. Immunological and pathological status of gilthead sea bream (Sparus aurata L.) under different long-term feeding regimes. Aquaculture 220: 707-724.

Statistical Institute [SAS]. 1991. SAS/STAT: User's Guide, Release 6.08. SAS Institute, Cary, NC, USA.

Steel, R.G.D.; Torrie, J.H. 1980. Principles and Procedures of Statistics: A Biometrical Approach. 2ed. McGraw-Hill, New York, NY, USA.

Urán, P.A.; Schrama, J.W.; Rombout, J.H.W.M.; Obach, A.; Jensen, L.; Koppe, W.; Verreth, J.A.J. 2008. Soybean mealinduced enteritis in Atlantic salmon (Salmo salar L.) at different temperatures. Aquaculture Nutrition 14: 324-330.

Van den Ingh, T.S.G.A.M.; Krogdahl, Å.; Olli, J.J.; Hendriks, H.G.C.J.M.; Koninkx, J.G.J.F. 1991. Effects of soybeancontaining diets on the proximal and distal intestine in Atlantic salmon (Salmo salar): a morphological study. Aquaculture 94: 297-305.

Vega, J.R.; Gibson, C.A.; Skaar, T.C.; Hadsell, D.L.; Baumrucker, C.R. 1991. Insulin-like growth factor (IGF)-I and IGF binding proteins in serum and mammary secretions during the dry period and early lactation in dairy cows. Journal of Animal Science 69: 2538-2547.

Wolke, R.E. 1992. Piscine macrophage aggregates: a review. Annual Review of Fish Diseases 2: 91-108.

Received November 25, 2009

Accepted May 14, 2010 